\title{
Synthetic Biology: A Promising Technology for Biofuel Production
}

\section{Kamaljeet Kaur Sekhon* and Pattanathu KSM Rahman}

\section{School of Science \& Engineering, Technology Futures Institute, Teesside University, Middlesbrough, UK}

With the increasing awareness among the masses and the depleting natural resources and oil reservoirs, a replacement for the fossil fuels is urgently required. There are rising global concerns about climate change and energy security. The current biofuel production trends are no doubt promising and increasing steadily. The biofuel markets are getting bigger and better in the European Union, USA, Brazil, India, China and Argentina and contributing to their bio-economies, respectively. In the US, biodiesel production exceeded 1 billion gallons in 2012 and reports claim that the global biofuels market will touch the figure of $\$ 185$ billion in 2021 . However the big question is: will the current biofuel production rate be able to meet the escalating transportation fuel demands?

The total estimated generation of biomass in the world is 150 billion tons annually. Increase in the production of biofuels in the recent years and the usage of edible commodities like maize, sugarcane and vegetable oil has led to the worldwide apprehension towards the future of biofuels and to the 'food $v$ s fuel' debate. The second generation biofuels, however, are produced from renewable, cheap and sustainable feed-stocks for example citrus peel, corn stover, sawdust, bagasse, straw, rice peel and are attracting ever-increasing attention. A great deal of research, by the scientific community, is carried out in various parts of the world in order to improve the yield of second generation biofuels to meet the future demands but hasn't achieved any remarkable success.

Sustainable, economic production of second generation biofuels is of global importance. However, major technological hurdles remain before widespread conversion of non-food biomass into biofuel. Various multi-disciplinary teams of scientists, technologists and engineers work together collaboratively in integrated teams to carry out research that underpins the generation and implementation of sustainable second generation biofuels from algal biomass using biological processes. The advantages of algal biomass from both micro and macroalgae as a raw material for producing biofuels have been well recognised for decades. Billions of tonnes of algal biomass are enzymatically converted into food energy by marine and freshwater animals and microbes every day, in a sustainable manner. However, the industrial, enzyme driven conversion of such biomass for bioenergy applications is still in its infancy.

The production of commercially attractive biofuels using enzymatic methods, all the same, is not as easy as it appears. The various polysaccharides viz. cellulose, starch, lignin, hemicellulose, or lignocellulosesneed tobeenzymaticallydegradedfortheirtransformation into glucose or sugar molecules which in turn are fermented into biofuels (bioethanol or biobutanol). In case of cellulose, the process of cellulolysis involves enzymes like cellulases and glucosidases. Cellulases are expensive, unstable and slow in action; therefore they increase the overall economics of the process of cellulolysis and hence biofuel production. The bulk production of cellulases at industrial level seems to be the relevant solution. The microbes that produce cellulases include symbiotic anaerobic bacteria (e.g. Cellulomonasfimi, Clostridium thermocellum, Clostridium phytofermentans, Thermobifidafusca) found in ruminants such as cow and sheep, flagellate protozoa present in hindguts of termites, and filamentous fungi isolated from decaying plants (e.g. Hypocreajecorina, Thermoascusaurantiacus, Phanerochaetechrysosporium, Neurosporacrassa, Tricodermareesei, Asperigillusniger, Fusariumoxysporum). The gene(s) responsible for cellulase production are characterized, isolated and recombinantly introduced into Escherichia coli for the enhancedcellulase expression levels.

Apart from the conventional biotechnology methods for biofuel production, synthetic biology has shown promising results lately. Understanding the DNA sequences, precisely measuring the gene behaviour paves way for fabricating or synthesizing the cellulase gene de novo. To put it in simple words, synthetic biology is a science of designing and constructing new biological parts, devices and systems for programming cells and organisms and endowing them with novel functions. It is a technique of writing the DNA / genetic code base by base using several computational tools and software's like Gene designer, GenoCAD, Eugene and Athena to name a few. Gene designer is a DNA design tool for de novo assembly of genetic constructs, GenoCAD is a computer-assisted-design application for synthetic biology for designing complex gene constructs and artificial gene networks, Eugene is a language designed to develop novel biological devices and Athena is a CAD / CAM software for constructing biological models as modules. These synthetic biology approaches can be useful in bringing down the cost of cellulases and, thereby, of biofuels. Several companies are spending a fortune on the production of bioethanol for example; Amyris Biotechnologies, Verenium, Iogen, Bioethanol Japan, Mascoma, POET, SolixBiofuels, Pacific Ethanol, NextGen Fuel Inc. and Jatro Diesel. However, the cost-effective production of the second generation biofuels is still a cherished desire of the scientific community.

Synthetic biology is an evolving field still dealing with the inherent complexity of biological systems and overcoming the biosafety issues involved with engineering the living systems. Indeed the proliferation of the computer modelling tools is leading to the revolution of this discipline which might write the success story of some of the present and future scientific challenges.

\footnotetext{
*Corresponding author: Kamaljeet Kaur Sekhon, School of Science \& Engineering, Technology Futures Institute, Teesside University, Middlesbrough, UK, Tel: 441642 218121; E-mail: kamalsekhon80@yahoo.com

Received November 20, 2013; Accepted November 21, 2013; Published November 28, 2013

Citation: Sekhon KK, Rahman PKSM (2013) Synthetic Biology: A Promising Technology for Biofuel Production. J Pet Environ Biotechnol 4: e121. doi:10.4172/2157-7463.1000e121

Copyright: (c) 2013 Sekhon KK, et al. This is an open-access article distributed under the terms of the Creative Commons Attribution License, which permits unrestricted use, distribution, and reproduction in any medium, provided the original author and source are credited.
} 